\title{
THE EFFECT OF SERVICE QUALITY ON CUSTOMER LOYALTY THROUGH CUSTOMER SATISFACTION AT ONE DOZEN CAFÉ OF BATAM
}

\author{
Gosal Diana Lestari, Bernardus Denny \\ University of Ciputra, Indonesia \\ *E-mail: diana lestgo@yahoo.com \\ ORCID: 0000-0002-5477-6061
}

\begin{abstract}
One Dozen Café (ODC) is the first pioneer of the local café in Batam City in which previously there were only coffee shops and cafés that could only be found inside the mall. ODC is a café that serves Indonesian cuisine by presenting a modern atmosphere in the midst of the Batam people's lifestyles which are full of Malay culture. The ODC's market target is young people, families and business people. The objectives of this research include: (1) Does service quality affect customer satisfaction in One Dozen Café of Batam? (2) Does customer satisfaction affect customer loyalty in One Dozen Café of Batam? (3) Does service quality affect customer loyalty in One Dozen Café of Batam? The research method used is the Partial Least Square (PLS) analysis approach which is part of the Structural Equation Modeling (SEM). This study applied quantitative method by distributing questionnaires to 100 respondents who became the research samples in which they were selected by using purposive sampling technique with criteria that they had made a minimum visit of three times. The findings showed that service quality and customer satisfaction affect customer loyalty. Service quality affects customer loyalty by $55.4 \%$ and the rest is affected by other factors.
\end{abstract}

\section{KEY WORDS}

Service quality, customer, satisfaction, customer loyalty.

Changes in society's lifestyles, which are now becoming more consumptive, are accompanied by the emergence of many businesses, especially in the fields of hotels, restaurants and cafés. There are many restaurants and cafés that currently do not only aim to meet the need for hunger, but they become part of the lifestyle or personal image (brand image) of someone. The existence of these changes and the new demands that exist in the society can be an opportunity and business growth especially in the hotel, restaurants and café industry group.

Restaurants and cafés experience a growth of around 50-500 new units that are established every year in Indonesia. This growth rate can be a sign of market demand for this industry. However, another thing to note is that this growth also leads to tight market competition. Business owners need to compete tightly to attract customers' attention or attempt to maintain customer loyalty. According to Kotler and Keller (2016), customers have new capabilities in which they can empower technological development. In addition to technology empowerment, customers will also move to other brands if they think that they are not treated properly or it does not meet their expectation. It is concluded that currently customers can easily move the choice of products or services when they feel dissatisfied with the services provided.

According to Nainggolan and Pradhanawati (2016), service quality is focused on efforts to meet customer needs and desires as well as the accuracy of delivery to offset customer expectations. Jimanto (2014) defines the quality of service as a measure of how well the level of service provided can be in accordance with customer expectations. Therefore, it can be concluded that the quality of service is our effort to meet customer expectations for the products or services we offer. Therefore, service quality is one of the factors that need to be considered in the sustainability of a business. When customers' expectations can be fulfilled properly, the expected result is that customers will be satisfied with what we offer. Broadly speaking, there are attributes that need to be considered to assess customer satisfaction, i.e. 
conformity of expectations, interest in revisiting, and willingness to recommend (Tjiptono, 2004). Moreover, in assessing customer loyalty there are also indicators that are similar to customer satisfaction. It was explained by Kotler and Keller (2016) that it has three indicators i.e. repurchase, retention, and referrals. This is what is often mentioned that customer satisfaction will go hand in hand with customer loyalty to a product or service.

One Dozen Café (ODC) is the first pioneer of the local café in Batam City in which previously there were only coffee shops and cafés that could only be found inside the mall. It was established in September 2015, ODC was established by PT Sukses Sabar Sentosa consisting of 12 shareholders. They are a group of businessmen who gather in the café every month to discuss and share stories about business. Skill in seeing business opportunities becomes one of the basics to the establishment of ODC.

ODC is a café that serves Indonesian cuisine by presenting a modern atmosphere in the midst of the Batam people's lifestyles which are full of Malay culture and kopitiam. The ODC's market target is young people, families and business people. Since its establishment, ODC was well received by Batam people and tourists coming from Singapore and Malaysia. As many as $70 \%$ of the customers who come to ODC are the repeaters. Along with the time development, the area around ODC began to develop and rivals around the ODC location began to appear with a distance of less than 500 meters. Tre Cipolle and Chemistree is a new café that was established around the ODC area precisely in mid-2016. Tre Cipolle is a café whose interior is identical for young people and the menu is more western-oriented; as well as Chemistree. The attraction of this place is the concept of nature and interior design, in which there is a very large giant tree that rises out of the building in the center part of the café.

Based on data collected through customer reviews using Google Review and TripAdvisor from 2017 to the early 2018, the quality of the product (taste and appearance) and prices received good reviews from the customers. However, places and services/facilities are also often discussed. A comparison between positive and negative ratings has a very close difference. So far, the services provided by ODC have been based on standard services such as opening the doors for the customers, greeting, and delivering them to seats, taking orders until orders are delivered to them. This has attracted the attention of researchers to discuss whether service quality has an effect to the decline in turnover which also causes a decrease in customer visits. In fact, the previous discussion mentions that most ODC customers are repeaters. According to Nainggolan and Pradhanawati, (2016) service quality affects customer satisfaction; the higher the quality of service, the higher the level of customer satisfaction. It is stated that the higher the availability of facilities provided, it will increase customer satisfaction and the desire to revisit. However, according to Jimanto (2014), service quality does not have a positive effect to customer loyalty in retail cinemas of the premiere. This happened because of the lack of unique value obtained by customers, where customers feel able to get the same service at a more affordable price.

Based on the above background, the formulation of the research problems includes:

- Does service quality affect customer satisfaction in One Dozen Café of Batam?

- Does customer satisfaction affect customer loyalty in One Dozen Café of Batam?

- Does service quality of affect customer loyalty in One Dozen Café of Batam?

Based on the formulation of the above problems, the research objectives include:

- Determining and analyzing the effect of service quality to customer satisfaction in One Dozen Café of Batam;

- Determining and analyzing the effect of customer satisfaction to customer loyalty in One Dozen Café of Batam;

- Determining and analyzing the effect of service quality to customer loyalty in One Dozen Café of Batam.

Hypotheses. Based on the above analysis model, the following hypotheses will be tested in this research that include: 
- Service quality has positive effect to customer satisfaction in One Dozen Café of Batam;

- Customer satisfaction has positive effect to customer loyalty in One Dozen Café of Batam;

- Service quality has positive effect to customer loyalty in One Dozen Café of Batam.

\section{METHODS OF RESEARCH}

This research applies a quantitative approach. Quantitative research, according to Sugiyono (2015), is a method that uses several samples and numerical data. This research aims to determine the effect of service quality to customer loyalty through customer satisfaction.

The research method used is the Partial Least Square (PLS) analysis approach which is part of the Structural Equation Modeling (SEM). This Partial Least Square Analysis aims to describe the correlation between variables in which customer satisfaction is the intervening variable. In addition, it can test the direct or indirect correlation between variables in the model (Ghozali, 2015) which later will be processed using the SmartPLS 2.0 program. The PLS method was chosen for this research due to limited information and the small number of samples used. It also does not require normally distributed data, is able to model many exogenous and endogenous variables (complex models), and results remain robust even though there are abnormal and missing data; in addition, it can be used in reflective and formative constructs (Abdillah and Jogiyanto, 2009).

The population of this research are customers of One Dozen Café in unknown or infinite amounts. Based on the unknown population and the limited access of the researcher to calculate the population with certainty, this research will use the Lemeshow (1997) formula to determine the number of samples. This research establishes 100 samples which are the customers of One Dozen Café, which will later be selected using probability sampling method with purposive sampling technique based on predetermined criteria; they have visited One Dozen Café for at least three times (Hosmer et al, 1997).

This step is to design a structural model of the correlation between latent variables based on the formulation of the research problems and the theory-based research hypothesis. The PLS method will allow for exploration of the correlation between latent variables (inner models) (Jaya and Sumertajaya, 2008).

The design stage of the measurement model (outer model) is very important because it is related to determining whether the indicators of each latent variable are reflective or formative (Jaya and Sumertajaya, 2008) in which it is determined based on the theory, previous research and or rationality. In this research, the variables are reflective.

After doing the first and second steps, the results of the design of the inner model and the outer model will be presented in the form of path diagram so that the results are more easily understood (Jaya and Sumertajaya, 2008).

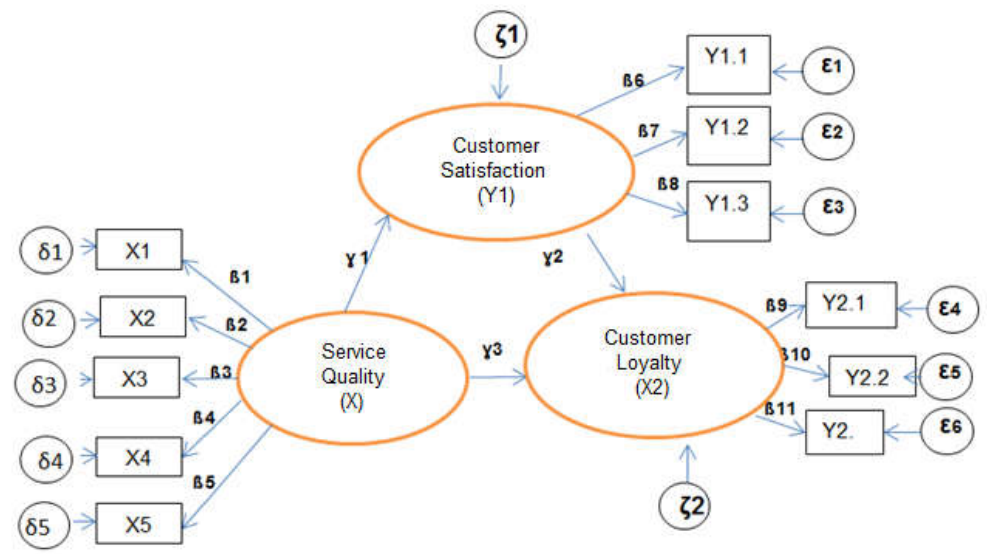

Figure 1 - Construction of Path Diagram 
The hypotheses are tested by using the bootstrap resampling method which allows data to be freely distributed, do not require the assumption of a normal distribution, and do not need large samples. The test is conducted by t-test in which the effect between variables in the research is significant if the t-statistic value $>$ t-table (1.96) with a significance value of 0.05. If the measurement results in the outer model are significant (t-statistics $>1.96$ ), then the indicator can be used as an instrument of the latent variables. If the measurement results in the inner model are significant (t-statistic > 1.96) then there is a significant effect of exogenous latent variables to endogenous latent variables.

Mediation variables or intervening variables are mediating variables of the correlation between exogenous variables and endogenous variables. This research also tests the mediating effect to find out the type of mediation of the latent variable of customer satisfaction. Determination of the mediation type uses the mediation type chart as follows:

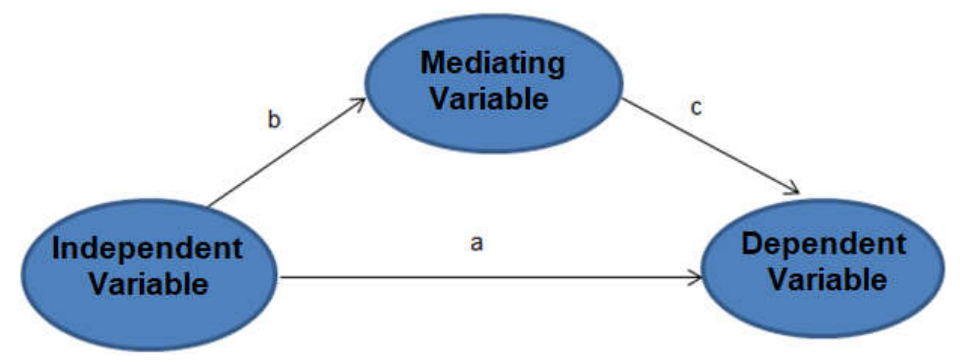

Figure 2 - Structural Model with the Mediation Variable (Source: Zhou et al, 2010)

The explanation in the above diagram is: if the direct effect value (a) is bigger than the indirect effect value $(b \times c)$, then the mediator variable has no effect. Meanwhile, if the direct variable value $(a)$ is smaller than the indirect effect $(b \times c)$, the mediator variable has an effect.

\section{RESULTS OF STUDY}

Partial Least Square Analysis. In this research, Partial Least Square (PLS) analysis research is applied to test the research hypotheses using the SmartPLS program. The following is the figure of the PLS model:

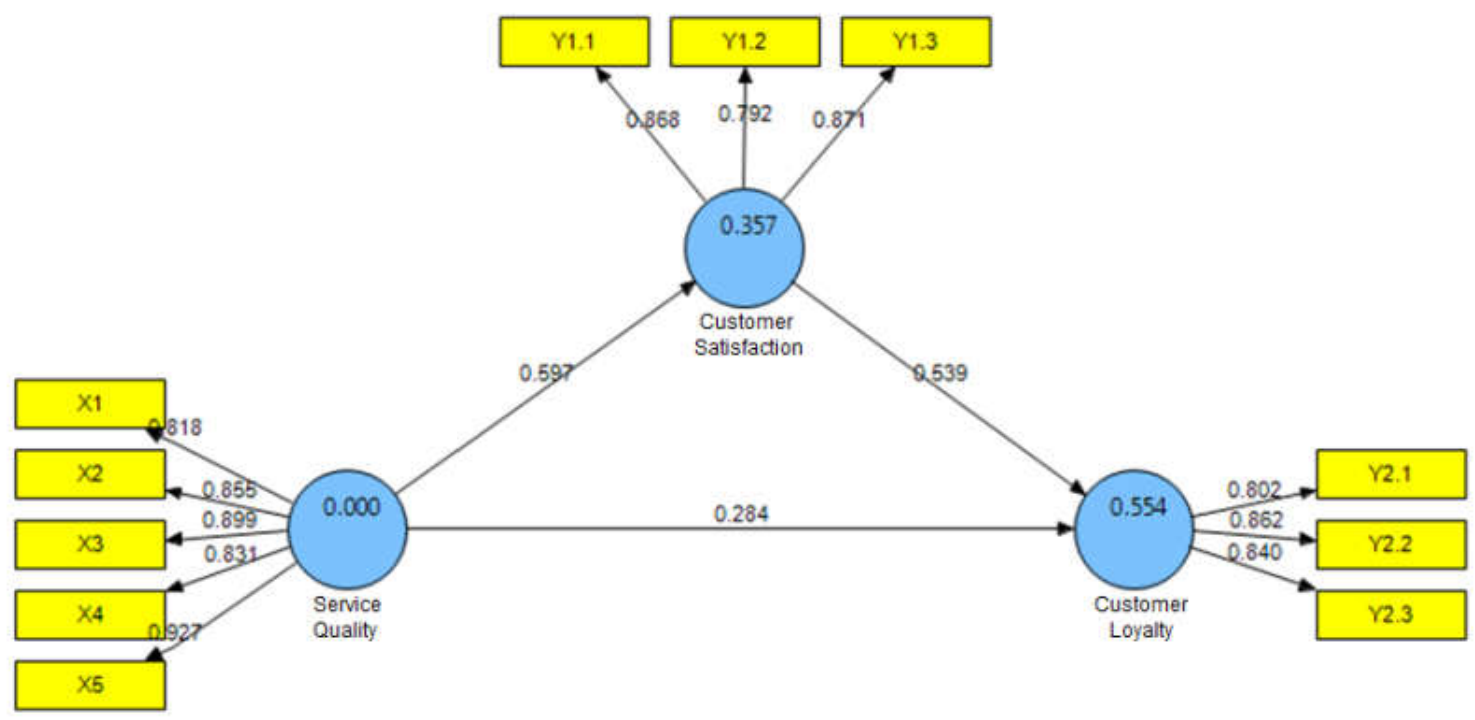

Figure 3 - Estimation Results of the PLS Model 
Testing the indicator reliability is carried out by looking at the outer loading value. An indicator meets the reliability indicator if it has the value of outer loading $>0.7$. the following is the outer loading value of each indicator:

Table 1 - Outer Loading Values

\begin{tabular}{|c|c|c|}
\hline Variables & Indicators & Outer Loading \\
\hline \multirow{4}{*}{ Service Quality } & $\mathrm{X} 1$ & 0.818 \\
\cline { 2 - 3 } & $\mathrm{X} 2$ & 0.855 \\
\cline { 2 - 3 } & $\mathrm{X} 3$ & 0.899 \\
\cline { 2 - 3 } & $\mathrm{X} 4$ & 0.831 \\
\cline { 2 - 3 } & $\mathrm{X} 5$ & 0.927 \\
\hline \multirow{3}{*}{ Customer Satisfaction } & $\mathrm{Y} 1.1$ & 0.868 \\
\cline { 2 - 3 } & $\mathrm{Y} 1.2$ & 0.792 \\
\cline { 2 - 3 } & $\mathrm{Y} 1.3$ & 0.871 \\
\hline \multirow{3}{*}{ Customer Loyalty } & $\mathrm{Y} 2.1$ & 0.802 \\
\cline { 2 - 3 } & $\mathrm{Y} 2.2$ & 0.862 \\
\cline { 2 - 3 } & $\mathrm{Y} 2.3$ & 0.840 \\
\cline { 2 - 3 } & &
\end{tabular}

Based on Table 1, it is found that all indicators used to measure variables have the outer loading value $>0.7$. Based on these results, it can be concluded that the evaluation on indicator reliability has met the requirements.

The discriminant validity test is carried out by looking at the cross-loading values and Fornell-Larcker. An indicator is considered to meet discriminant validity if the value of crossloading indicator in the variable is the biggest compared to other variables. The following is the cross-loading value of each indicator:

Table 2 - Cross Loading Values

\begin{tabular}{|c|c|c|c|c|}
\hline \multirow{3}{*}{ Indicators } & \multicolumn{3}{|c|}{ Variables } & \multirow{2}{*}{ Evaluation } \\
\cline { 2 - 4 } & $\begin{array}{c}\mathrm{X} \\
\text { Service Quality }\end{array}$ & $\begin{array}{c}\text { Y1 } \\
\text { Customer Satisfaction }\end{array}$ & $\begin{array}{c}\text { Y2 } \\
\text { Customer Loyalty }\end{array}$ & \\
\hline $\mathrm{X} 1$ & 0.818 & 0.599 & 0.573 & Valid \\
\hline $\mathrm{X} 2$ & 0.855 & 0.455 & 0.516 & Valid \\
\hline $\mathrm{X} 3$ & 0.899 & 0.513 & 0.513 & Valid \\
\hline $\mathrm{X} 4$ & 0.831 & 0.444 & 0.450 & Valid \\
\hline $\mathrm{X} 5$ & 0.927 & 0.551 & 0.555 & Valid \\
\hline Y1.1 & 0.545 & 0.868 & 0.657 & Valid \\
\hline Y1.2 & 0.447 & 0.792 & 0.488 & Valid \\
\hline Y1.3 & 0.514 & 0.871 & 0.633 & Valid \\
\hline Y2.1 & 0.493 & 0.578 & 0.802 & Valid \\
\hline Y2.2 & 0.510 & 0.574 & 0.862 & Valid \\
\hline Y2.3 & 0.514 & 0.621 & 0.840 & Valid \\
\hline
\end{tabular}

Based on Table 2, each indicator has the largest cross-loading value on the variable that they form compared to other variables. Thus, it can be concluded that the indicators used in this research have good discriminant validity in compiling their respective variables. Meanwhile, the assessment using Fornell-Larcker is carried out by comparing the value of the AVE roots of each variable with the correlation between variables. If the value of the root AVE is bigger than the correlations then the variable has good discriminant validity. The following are the results of discriminant validity test using the Fornell-Larcker method:

Table 3 - AVE Root Value and Correlation between the Variables (Fornell-Larcker)

\begin{tabular}{|c|c|c|c|c|c|}
\hline Variables & AVE & $\sqrt{ }$ AVE & X & Y1 & Y2 \\
\hline X- Service Quality & 0.752 & 0.876 & 0.867 & & \\
\hline Y1- Customer Satisfaction & 0.713 & 0.844 & 0.597 & 0.844 & \\
\hline Y2 - Customer Loyalty & 0.697 & 0.835 & 0.606 & 0.709 & 0.835 \\
\hline
\end{tabular}

Table 3 shows that all correlation values are smaller than the root value of AVE. These results indicate that each variable in this research has good discriminant validity. 
Internal Consistency. A variable meets construct reliability if it has a composite reliability value $>0.7$. the following is the composite reliability value of each variable:

Table 4 - Composite Reliability Values

\begin{tabular}{|c|c|c|c|}
\hline Variables & Composite Reliability & Rule of Thumb & Evaluation \\
\hline Service Quality & 0.938 & \multirow{3}{*}{$>0.70$} & Reliable \\
& 0.881 & Reliable & Reliable \\
\hline Customer Satisfaction & 0.873 & & \\
\hline Customer Loyalty & & &
\end{tabular}

Table 4 shows that the composite reliability value of each variable $>0.7$. Thus, in this research model, each variable has fulfilled the construct reliability.

Table 5 - Cronbach Alpha Values

\begin{tabular}{|c|c|c|c|}
\hline Variables & Cronbach Alpha & Rule of Thumb & Evaluation \\
\hline Service Quality & 0.917 & \multirow{3}{*}{$>0.70$} & Reliable \\
& 0.799 & Reliable \\
\hline Customer Satisfaction & 0.782 & & Reliable \\
\hline Customer Loyalty & & &
\end{tabular}

Table 5, regarding the results of Cronbach's Alpha, shows that the Cronbach's Alpha value for the three latent variables of service quality, customer satisfaction and customer loyalty have values greater than 0.7 . Therefore, it can be considered that the three latent and measuring variables used in this research are reliable.

Convergent Validity. Convergent validity test is carried out by using the AVE value. The conditions used are the AVE values must be bigger than 0.5 so that it can meet the convergent validity. The following is the AVE value of each latent variable:

Table 6 - AVE (Average Variance Extracted) Values

\begin{tabular}{|c|c|c|c|}
\hline Variables & AVE & Rule of Thumb & Evaluation \\
\hline Service Quality & 0.752 & & Valid \\
\cline { 1 - 2 } & 0.713 & $>0.5$ & Valid \\
\hline Customer Satisfaction & 0.697 & & Valid \\
\hline Customer Loyalty & & \\
\hline
\end{tabular}

Table 6, concerning the AVE results, shows that the AVE value for each latent variable of service quality, customer satisfaction and customer loyalty have values of more than 0.5 . Therefore, it can be considered that all three latent variables are valid and do not have convergent validity problems.

The data processing using PLS produces the R-Square values as follows:

Table $7-R^{2}$ Values

\begin{tabular}{|c|c|}
\hline Endogen Variables & Nilai R-Square \\
\hline Customer Satisfaction & 0.357 \\
\hline Customer Loyalty & 0.554 \\
\hline
\end{tabular}

Based on Table 7, it is known that the R-Square value for customer satisfaction is 0.357 , which means that the percentage of customer satisfaction that can be explained by the quality of service is $35.7 \%$. Meanwhile, the value of R-Square for customer loyalty is 0.554 which means that the percentage of customer loyalty that can be explained by service quality and customer satisfaction is $55.4 \%$.

Based on the data processing by using PLS, the Q-Square values are as follows:

Table $8-Q^{2}$ Values

\begin{tabular}{|c|c|}
\hline Endogenous Variables & Q-Square Values \\
\hline Customer Satisfaction & 0.418 \\
\hline Customer Loyalty & 0.363 \\
\hline
\end{tabular}


Based on Table 8, it is known that the Q-Square value is greater than 0 , which means that the model has good predictive relevance. The variable value of customer satisfaction is 0.418 and the value of the variable customer loyalty is 0.36 ; both are considered to have values greater than 0 so they are good. In the PLS model, the assessment of goodness of fit is known from the $Q-S q u a r e$ value which can be seen in the above table. The value of $Q$ Square has the same meaning as the coefficient of determination (R-Square) in the regression analysis; the higher the R-Square, the model will be more fit with the data. From the R-Square value generated by PLS program, the Q-Square value can be calculated as the following:

$$
\text { Q-Square Value }=1-[(1-0.357) \times(1-0.554)]=0.713
$$

From the results of calculations, it is known that the Q-Square value is 0.713 . It means that the diversity of research data that can be explained by the research model is $71.3 \%$, while the remaining $28.7 \%$ is explained by other factors outside the model. Based on these results, the model in the research has appropriate goodness of fit. following:

Based on data processing by using PLS, it produces the R-Square values as the

Table $9-f^{2}$ Values

\begin{tabular}{|c|c|c|c|}
\hline & Customer Satisfaction & Service Quality & Customer Loyalty \\
\hline Service Quality & 0.555 & - & 0.116 \\
\hline Customer Satisfaction & - & - & 0.420 \\
\hline Customer Loyalty & - & - & - \\
\hline
\end{tabular}

Based on Table 9, it is found that the f-Square value for service quality and customer satisfaction is 0.555 which has big effect, the f-square value of service quality and customer loyalty is 0.116 which has medium effect and f-square value customer satisfaction and customer loyalty is 0.420 which has big effect. Overall, most of the f-square values have big effect.

The hypothesis test is carried out by looking at the coefficient of the effect and the tstatistics generated by the structural model (inner model) in PLS. The hypothesis can be accepted if the coefficient of the effect is positive and t-statistics $>1.96$.

The following are the coefficients and t-statistics on the outer model and inner model produced by the structural model (inner model):

Table 10 - Hypothesis Test on the Outer Model of Service Quality

\begin{tabular}{|c|c|c|}
\hline $\mathrm{n} / \mathrm{n}$ & Original Sample $(\mathrm{O})$ & T Statistics $(|\mathrm{O} / \mathrm{STERR}|)$ \\
\hline $\mathrm{X} 1<-$ Service Quality $(\mathrm{X})$ & 0.818336 & 18.082204 \\
\hline $\mathrm{X} 2<-$ Service Quality $(\mathrm{X})$ & 0.855345 & 20.716553 \\
\hline $\mathrm{X} 3<-$ Service Quality $(\mathrm{X})$ & 0.899252 & 30.878546 \\
\hline $\mathrm{X} 4$ <- Service Quality $(\mathrm{X})$ & 0.831460 & 18.149153 \\
\hline $\mathrm{X} 5$ <- Service Quality $(\mathrm{X})$ & 0.927110 & 50.738788 \\
\hline
\end{tabular}

Based on Table 10, regarding the results of the outer loading of service quality variable, it shows that the t-statistic value for each indicator is more than 1.96. It can be seen based on the following equation:

$$
\begin{aligned}
& X 1=ß 1 . X+\delta 1=(0.818 \times 0.000)+0.05=0.5 \\
& X 2=\beta 2 . X+\delta 2=(0.855 \times 0.000)+0.05=0.5 \\
& X 3=\beta 3 . X+\delta 3=(0.899 \times 0.000)+0.05=0.5 \\
& X 4=ß 4 . X+\delta 4=(0.831 \times 0.000)+0.05=0.5 \\
& X 5=\beta 5 . X+\delta 5=(0.927 \times 0000)+0.05=0.5
\end{aligned}
$$


Based on these results, it is found that the five indicators on service quality variable have a positive value and can be used as a measure of service quality variable.

Table 11 - Hypothesis Test on Outer Model of Customer Satisfaction

\begin{tabular}{|c|c|c|}
\hline $\mathrm{n} / \mathrm{n}$ & Original Sample $(\mathrm{O})$ & T Statistics $(|\mathrm{O} / \mathrm{STERR}|)$ \\
\hline $\mathrm{Y} 1.1<-$ Customer Satisfaction $(\mathrm{Y} 1)$ & 0.867611 & 28.021881 \\
\hline $\mathrm{Y} 1.2<-$ Customer Satisfaction $(\mathrm{Y} 1)$ & 0.791780 & 15.316411 \\
\hline $\mathrm{Y} 1.3<-$ Customer Satisfaction $(\mathrm{Y} 1)$ & 0.870770 & 26.881924 \\
\hline
\end{tabular}

Based on Table 11, regarding the results of the outer loading of customer satisfaction variable, it shows that the t-statistic value for each indicator has value more than 1.96 . It can be seen based on the following equation:

$$
\begin{aligned}
& Y 1.1=ß 6 . Y 1+\varepsilon 1=(0.868 \times 0.357)+0.05=0.375 \\
& Y 1.2=\beta 7 . Y 1+\varepsilon 2=(0.792 \times 0.357)+0.05=0.333 \\
& Y 1.3=\beta 8 . Y 1+\varepsilon 3=(0.871 \times 0.357)+0.05=0.342
\end{aligned}
$$

Based on these results, it is found that the three indicators on the customer satisfaction variable have positive values and can be used as a measure of the customer satisfaction variable.

Table 12 - Hypothesis Test on Outer Model of Customer Loyalty

\begin{tabular}{|c|c|c|}
\hline & Original Sample (O) & T Statistics (|O/STERR|) \\
\hline Y2.1 <- Customer Loyalty (Y2) & 0.801511 & 18.387566 \\
\hline Y2.2 <- Customer Loyalty (Y2) & 0.862256 & 23.994681 \\
\hline Y2.3<- Customer Loyalty (Y2) & 0.839705 & 23.196834 \\
\hline
\end{tabular}

Based on Table 12, regarding the results of the outer loading of customer loyalty variable, it shows that the t-statistic value for each indicator has a value of more than 1.96 . It can be seen based on the following equation:

$$
\begin{aligned}
& Y 2.1=ß 9 . Y 2+\varepsilon 4=(0.802 \times 0.554)+0.05=0.494 \\
& Y 2.2=ß 10 . Y 2+\varepsilon 5=(0.864 \times 0.554)+0.05=0.529 \\
& Y 2.3=ß 11 . Y 2+\varepsilon 6=(0.840 \times 0.554)+0.05=0.515
\end{aligned}
$$

Based on these results, it is found that all three indicators on customer loyalty variable have positive values and can be used as a measure of customer loyalty variable.

Table 13 - Hypothesis Test of Inner Model

\begin{tabular}{|c|c|c|c|c|}
\hline Hypotheses & Effect & Coefficient & Standard Error & t-statistics \\
\hline H1 & Service Quality $\rightarrow$ Customer Satisfaction & 0.597 & 0.092 & 6,461 \\
\hline H2 & Customer Satisfaction $\rightarrow$ Customer Loyalty & 0.539 & 0.101 & 5,352 \\
\hline H3 & Service Quality $\rightarrow$ Customer Loyalty & 0.284 & 0.109 & 2,597 \\
\hline
\end{tabular}

The coefficient of effect on the service quality to customer satisfaction is 0.597 with a tstatistic of $6.461>1.96$. It shows that there is a significant positive effect between the correlation of service quality and customer satisfaction in One Dozen Café of Batam. In other words, if the service quality provided to customers is getting better, it will significantly increase customer satisfaction. The equation is $Y 1=\gamma 1 x+\zeta 1=(0.597 \times 0.000)+0.05=$ 0.05 . Based on these results, $\mathrm{H} 1$, which assumes that service quality has positive effect to customer satisfaction, is accepted.

The coefficient of effect on the customer satisfaction to customer loyalty is 0.539 with a t-statistic of $5.352>1.96$. It shows that there is a significant positive effect between the correlation of customer satisfaction and customer loyalty in One Dozen Café of Batam. In other words, if customer satisfaction is getting better, it will significantly increase customer loyalty. The equation is $Y 2=\gamma 3 x+\gamma 2 Y 1+\zeta 2=(0.284 \times 0.000)+(0.539 \times 0.357)+0.05=$ 
0.242. Based on these results, $\mathrm{H} 2$, which assumes that customer satisfaction has positive effect to customer loyalty, is accepted.

The coefficient of effect on the service quality to customer loyalty is 0.284 with a tstatistic of $2.597>1.96$. It shows that there is a significant positive effect between the correlation of service quality and customer loyalty in One Dozen Café of Batam. In other words, if the quality of services provided to customers is getting better, it will significantly increase customer loyalty. The equation is $Y 2=\gamma 3 x+\gamma 2 Y 1+\zeta 2=(0,284 \times 0,000)+(0,539$ $x 0,357)+0,05=0,242$. Based on these results, $H 3$, which assumes that service quality has positive effect to customer loyalty, is accepted.

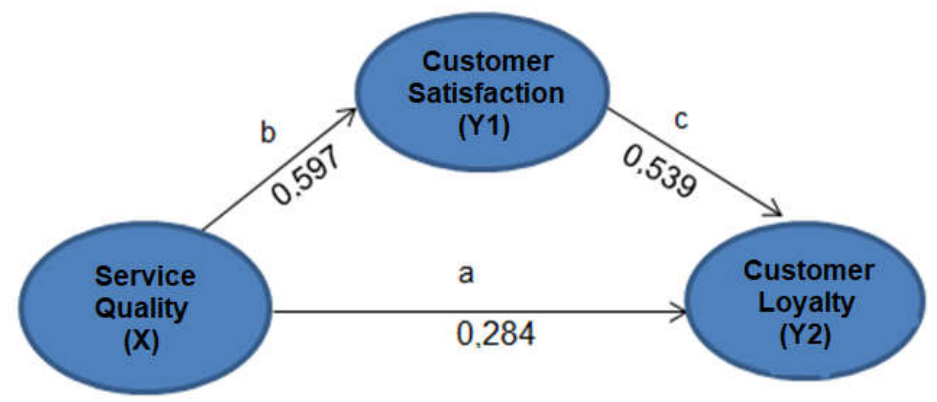

Figure 4 - Structural Models with Mediating Variable

Based on Figure 4, it seems that service quality has a direct effect to customer loyalty (path a) of 0.284 , direct effect to customer satisfaction of 0.597 (path b), and the direct effect of customer satisfaction to customer loyalty of 0.539 (path c). In the Figure 4, we can see the indirect effect of service quality to customer loyalty through customer satisfaction which is $0.597 \times 0.539=0.321$. In this case the direct (a) 0.284 variable value is smaller $(<)$ than the indirect variable $(b \times c) 0.321$, so the customer satisfaction variable has a mediating effect on the service quality to customer loyalty.

\section{DISCUSSION OF RESULTS}

Effect of Service Quality to Customer Satisfaction. Based on the analysis results of the hypothesis test, it is found that the t-statistic value of each service quality indicator is $>1.96$. So, the results show that the first hypothesis is accepted which describes that service quality has positive effect to customer satisfaction in One Dozen Café. These results explain that the more quality or the better the service quality provided, it will affect the increase in customer satisfaction and vice versa; if customers feel that the service quality provided is less quality, it will lead to customer dissatisfaction. The research findings are supported by Nainggolan, et al, (2016) who stated that service quality affects customer satisfaction. It is also supported in the research conducted by Subagiyo and Adlan (2017).

Lewis and Boom, in Jimanto (2014) defined service quality as a measure of how well the level of service provided can meet customer expectations. In this research, related to service quality, there are five indicators consisting of reliability, responsiveness, assurance, empathy, and tangible, each of which is represented by a statement responded by the respondent. Based on the results of respondents' answers, it was found that the lowest mean is in the responsiveness indicator with a mean value of 3.94 and the highest standard deviation of 0.963 in the statement of understanding customers in One Dozen Café. It means that the respondents' answers have a far range, in which there are customers who do not agree with the ability of One Dozen Café specifically in understanding customer needs. Based on the lowest mean value in the responsiveness indicator, it is necessary to try to improve service quality. Responsiveness consists of staff preparedness in receiving orders, responsive in serving customers, and understanding customer needs. Efforts that can be made are evaluating and training the employees such as making a list of mandatory questions given to guests to answer customer needs; for example, if the customer bring 
babies they will be offered baby seats, if customers order dessert menus they will be asked about the menu that will be served before or after main course. In terms of receiving orders, self-order innovation can be implemented and make call buttons when customers need something.

Effect of Customer Satisfaction to Customer Loyalty. Based on data analysis that has been conducted previously, the findings found that the second hypothesis is accepted which shows that customer satisfaction has positive effect to customer loyalty in One Dozen Café. The research findings are in line with the research conducted by Adji and Subagio (2013) and Palit, et al, (2016) who stated that customer satisfaction affects customer loyalty.

In customer satisfaction, there are three indicators consisting of: (1) services given by ODC meet my expectations (received 50 agreed responses from the customer); (2) I am interested in having revisit because I am satisfied with the services provided (received 45 agreed responses; and (3) I would recommend ODC to my colleagues because the services provided met my expectations (received the most agreed responses from 55 people).

These results explain that when the customers feel satisfied with the services provided which meet their expectations, then they will come back, and will recommend ODC to their colleagues. It will have an effect to customer loyalty of One Dozen Café. All these satisfaction variables have an average mean value of 4.11 , which means that the respondents agree that satisfaction affects loyalty. However, in the Y.1.2 indicator of "I am interested in revisiting again because the services provided meet my expectations" has a high standard deviation value of 0.821 , which means that the respondents' answers have a far enough range and there are customers who disagree to this. In this case, there are various other factors affecting customers to revisit ODC, i.e. product, price, promotion and location factors (Gage in Khusaini, 2016). Further research is required in this regard. However, in this case efforts can be made by establishing relationships with customers to be able to identify customer needs to improve and maintain their satisfaction. This effort can be made by creating social media platforms that can make customers easily obtain information about ODC. In addition, ODC can also follow the developments from their customers and the staffs can establish direct relationships during customer visits. This effort is in line with Tjiptono (2015) that the creation of customer satisfaction will provide several benefits, including: more harmonious relationships between companies and customers, a good basis for repurchase and loyalty, and form recommendation of positive influence that will be profitable for the company.

Effect of Service Quality to Customer Loyalty. Based on data analysis that has been carried out previously, it is obtained that the third hypothesis is accepted which showed that service quality has direct effect to customer loyalty with a significant value of 0.284 . This is in line with a research conducted by Laemonta and Padmalia (2016) which explained that service quality affects customer loyalty.

In customer loyalty, there are three indicators consisting of: (1) I will come back because I am satisfied with the services (received 50 agreed responses from the customers; (2) contra to negative issues about ODC and will still make revisit (received 57 agreed responses); and (3) always recommend ODC to other people (received the most agreed responses from 59 people). This overall variable has a total mean value of 3.86 which means that the average respondent agrees with the statements. However, on the Y.2.1 indicator with the statement "I came back because I am satisfied with the services of One Dozen Café" has a high standard deviation value of 0.935 which means that the respondents' answers have far range and there are some customers who disagree. It is the same as customer satisfaction that there are other factors that can affect why customers do not come back despite being satisfied with the services provided such as the product quality and the menu offered. According to the research findings of Jimanto (2014), it was found that customers are not loyal even though the service quality provided is good. The satisfied feeling is influenced by customers' feel that the benefits they obtain are not much more profitable when they are compared to offers with lower prices. In this case, ODC also needs to continue to pay attention to the quality of the product in which the price offered is offset by the quality of the services. In this research, based on the lowest standard deviation of 0.66 , it means that 
the average customer answer agrees to "always recommend One Dozen Café" that may support that there are other factors affecting this matter since it is assessed as a form of customer loyalty, as stated also in Palit, et al, (2016).

Mediation Effects. Based on the research findings, it is found that customer satisfaction proved to play a significant mediation between service quality and customer loyalty. Although customer satisfaction does not mediate the correlation between service quality and customer loyalty in full, customer satisfaction contributes partially as a mediating variable. It shows that some service quality variables to customer loyalty are mediated partially through customer satisfaction.

\section{CONCLUSION}

Based on the results of the analysis and discussion presented above, the conclusions of this research include: 1) service quality has positive effect to customer satisfaction in One Dozen Café of Batam. The first hypothesis is accepted, 2) the increasing service quality provided, the more customer satisfaction increased. Customer satisfaction has positive effect to customer loyalty in One Dozen Café of Batam. The second hypothesis is accepted. Increasing customer satisfaction is also increasing customer loyalty, 3) Service quality has positive effect to customer loyalty in One Dozen Café of Batam. The third hypothesis is accepted. The increasing the service quality provided, the more customer loyalty increases.

\section{REFERENCES}

1. Abdillah, W. \& Jogiyanto, H. M.,(2009). Konsep Dan Aplikasi PLS (Partial Least Square) Untuk Penelitian Empiris. Badan Penerbit Fakultas Ekonomi Dan Bisnis UGM, Yogyakarta.

2. Adji. P., \& Subagio, H (2013). Pengaruh retail mix terhadap keputusan pembelian mahasiswa uk petra di circle k siwalankerto sub. Jurnal Manajemen Petra.

3. Ghozali, I. (2015). Aplikasi Analisis Multivariate dengan Program IBM SPSS 23. Semarang : Badan Penerbit Universitas Diponegoro.

4. Hosmer, D. W. (1997). A comparison of goodness-of-fit tests for the logistic regression model. Statistics in medicine, 16(9), 965-980.

5. Jaya, I. G. N. M., \& Sumertajaya, I. M. (2008). Pemodelan persamaan struktural dengan partial least square. Semnas Matematika dan Pendidikan Matematika, 1, 118-132.

6. Jimanto, R. B. (2014). Pengaruh Service Quality Terhadap Loyalitas Pelanggan Dengan Customer Satisfaction Sebagai Variabel Intervening Pada Ritel Bioskop the Premiere Surabaya. Jurnal Strategi Pemasaran, 2(1), 1-7.

7. Kotler, P. (2016). Marketing Management . England. Pearson Education Limited.

8. Laemonta, J. H., \& Padmalia, M. (2017). Pengaruh Inovasi dan Kualitas Layanan terhadap Loyalitas Konsumen Terang Bulan-Martabak 93. Journal of Entrepreneur and Entrepreneurship, 5(2), 73-80.

9. Nainggolan, L. P., \& Pradhanawati, A. (2016). Pengaruh Kualitas Pelayanan, Keragaman Produk dan Lokasi Terhadap Kepuasan Pelanggan (Studi Kasus Pada Pelanggan Stove Syndicate Cafe di Semarang). Jurnal Ilmu Administrasi Bisnis, 5(4), 531-541.

10. Palit, H. C., Kristanti, M., Aysia, D. A. Y., \& Priskila, A. (2016). The Effect of Service Quality and Customer Satisfaction on Customer Loyalty of Small Scale Indonesian (Doctoral dissertation, Petra Christian University).

11. Subagiyo, R. (2017). Pengaruh Service Quality, Marketing Mix dan Kepuasan Mahasiswa terhadap Customer Loyalty. Jurnal Ekonomi Modernisasi, 13(1), 1-15.

12. Sugiyono. (2015). Metode penelitian dan pendidikan pendekatan kuantitas, kualitatif, dan R \& D. Bandung. Alfabeta.

13. Tjiptono Fandy dan Anastasia Diana. (2015). Pelanggan Puas ? Tak Cukup !. Andi. Yogyakarta.

14. Tjiptono, Fandy (2004), Manajemen Jasa. Undi.Jogja. 